\title{
CHANGES IN PROPERTIES OF A CLAYEY SOIL AFTER ADDING COMPOSTED AND UNCOMPOSTED GYTTJA
}

\author{
YAKUPOGLU, T. ${ }^{*}-$ DURMUS, M. ${ }^{2}-$ KARA, Z. $^{3}-$ KIZILKAYA, R. ${ }^{2}$ \\ ${ }^{I}$ Department of Soil Science \& Plant Nutrition, Faculty of Agriculture, Yozgat Bozok University, \\ Yozgat, Turkey \\ (phone: +90-354-242-1028; fax: +90-354-242-1096)
}

${ }^{2}$ Department of Soil Science \& Plant Nutrition, Faculty of Agriculture, Samsun Ondokuz Mayis University, Samsun, Turkey

(phone: +90-362-312-1919; fax: +90-362-457-6091)

${ }^{3}$ Department of Soil Science \& Plant Nutrition, Faculty of Agriculture, Kahramanmaras Sutcu Imam University, Yozgat, Turkey

(phone: +90-344-300-2001; fax: +90-344-300-2002)

*Corresponding author

e-mail: tugrul.yakupoglu@bozok.edu.tr; +90-354-242-1028; fax: +90-354-242-1096

(Received 29 $9^{\text {th }}$ Mar 2021; accepted $10^{\text {th }}$ Jun 2021)

\begin{abstract}
This study presents an incubation experiment that investigates the effects of adding composted and uncomposted gyttja on a clayey soil's structural stability and other properties. For this purpose, $3 \%$ $(\mathrm{w} / \mathrm{w})$ of the composted and uncomposted gyttja was added to pots with and without grass pea (Lathyrus sativus $\mathrm{L}$.) seeds and incubated for nine months under greenhouse conditions. In the third, sixth, and ninth months of the experiment, soil samples were tested. The results show that the time elapsed during the incubation period greatly affected the physical (average weighted diameter, aggregate stability, and volume weight) and chemical ( $\mathrm{pH}, \mathrm{EC}$, organic matter, $\mathrm{N}, \mathrm{P}, \mathrm{K}, \mathrm{Ca}, \mathrm{Mg}$, and $\mathrm{Na}$ ) properties of the soil. The input of composted and uncomposted gyttja caused significant changes in soil properties, but these were less pronounced in soils with composted gyttja.
\end{abstract}

Keywords: aggregate stability, mean weight diameter, soil conditioner, Vertisol

Abbreviations: BD: dry bulk density, Ca: extractable calcium in ammonium acetate, C-gyttja: composted gyttja, EC: Electrical conductivity value corrected for $25^{\circ} \mathrm{C}, \mathrm{N}$ : total nitrogen, $\mathrm{K}$ : extractable potassium in ammonium acetate, MDW: mean weight diameter, Mg: extractable magnesium in ammonium acetate, Na: extractable sodium in ammonium acetate, ns: not statistically significant, P: available phosphorus for plants, pH: soil reaction, SOM: soil organic matter content (w/w), UnC-gyttja: uncomposted gyttja, WAS: wet aggregate stability

\section{Introduction}

Since the industrial revolution, exponential population growth, urbanization, changes in production methods, and consumption habits have greatly increased environmental pollution. Waste is generated from many types of businesses, including the energy sector, which has a vital importance in the modern age. For thermal power plants, gyttja is waste material that is difficult to deal with. In order to extract lignite to operate thermal power plants, a layer called gyttja must be removed. It is usually 10-15 m thick and found at depths of 20-40 m. Pickling of this emerging gyttja is a process that needs to be managed from an environmental point of view.

Gyttja is a muddy freshwater deposit located near or under a lake. The term was first mentioned in 1862 by the Swedish scientist Hampus von Post. He defined gyttja as a 
light-gray to brown-black deposit made up of plankton particles in eutrophic waters, mollusk shells, insect shells, high plant content, pollen spores, and mineral particles (Stankevica et al., 2013; Yakupoglu et al., 2013). Gyttja may contain minerals (Miroslaw-Grabowska and Gasiorowski, 2010; Jarnuszewski and Meller, 2009) and has up to $50 \% \mathrm{CaCO}_{3}$ depending on its depth (Larsson, 1990; Becker et al., 2004).

During coal production, the average amount of gyttja extracted from lignite by the Afsin-Elbistan facilities operating in Turkey is around $14 \times 10^{6} \mathrm{Mg}$. The Afsin-Elbistan coal power plant, operating with the $\mathrm{A}$ and $\mathrm{B}$ units, has a reserve of $1.8 \times 10^{9} \mathrm{Mg}$ gyttja, which will reach $3.5-4 \times 10^{9} \mathrm{Mg}$ once the $\mathrm{C}$ and $\mathrm{D}$ units become operational (Saltali and Yildirim, 2016). Afsin-Elbistan lignite mines cover an area of approximately 12000 ha (Munsuz and Akyildiz, 1979) and are located in the basin of Turkey's largest lignite reserve (Avci, 2005). Lignite extraction continues to be carried out with the open operating method as part of the power plant project in this basin. Aside from the A and B units of the power plant that are already operational, C, D, E and F sectors can be found (Gunalay, 1971) in another area. Removing gyttja is a process that must be managed.

Organic content of gyttja in this basin is > 20\% (Karaca et al., 2006; Torun, 2009; Demirkiran and Cengiz, 2010). Heavy metal content in the soil does not exceed acceptable limits. When added to the soil in appropriate doses, gyttja may be used as a soil regulator. Soils cultivated in the world generally have low levels of organic matter (Edwards et al., 2000; Robertson et al., 2014; Bischoff et al., 2016) and this also applies to Turkey as well (Aydin et al., 2017). The most common way to address this deficiency is by adding vegetable and animal organic matter (Candemir and Gulser, 2011), but they may not be available in the required amounts. On the other hand, gyttja is abundant and does not have many other uses, so it has potential to be used on agricultural fields (Tamer and Karaca, 2006).

Although there have been many studies of gyttja as a soil conditioner (Torun et al., 2003; Stankevica et al., 2014; Demir et al., 2017; Namli et al., 2017, 2019; Yuce and Yakupoglu, 2017), these studies have mostly focused on plant nutrition and contamination caused by gyttja. However, the gyttja in these studies was only broken down into smaller particles and not composted, which is how it is found in nature. Adding gyttja to soil without composting may result in delayed effects and inadequate improvements in the physical properties of the soil such as aggregation compared to other organic materials (Musuz and Akyildiz, 1979). Natural organic materials should be composted and then added to the soil in order to provide faster and longer lasting effects, as is done for vegetable and animal organic materials (Del Buono et al., 2011; Gulser et al., 2015; Mpeketula and Snapp, 2018; Mekki et al., 2019).

This study presents the results of an incubation experiment. Adding composted and uncomposted gyttja to clayey soil changed its physical and chemical properties. Erosion control is also important in clay soils because perhaps they are relatively hard to erode but are easily transported when eroded. This soil was used a substrate to grow grass pea (Lathyrus sativus L.).

\section{Materials and methods}

\section{Soil}

As reported by Ersahin and Karahan (2015), the soils used in the incubation experiment were obtained from cultivated land in the Topcu Village in the Yozgat city, Turkey (44018175 N, $654331 \mathrm{E}, 1267 \mathrm{~m}$ asl). Its properties are given in Table 1 
(Yakupoglu, 2018). It is clay-based Vertisol (47.6\% clay, $13.8 \%$ silt, $38.6 \%$ sand), slightly salty $\left(\mathrm{EC}, 3.97 \mathrm{dS} \mathrm{m}^{-1}\right)$, has a neutral $\mathrm{pH}(7.09)$, is moderately calcic $(7.15 \%$ $\mathrm{CaCO}_{3}$ ), and has a medium organic matter content (2.49\%). The total $\mathrm{N}$ content is $0.15 \%$ and the available $\mathrm{P}_{2} \mathrm{O}_{5}$ is $179.3 \mathrm{ppm}$.

Table 1. Properties of the Vertisol before the experiment (Yakupoglu, 2018)

\begin{tabular}{c|c|c|c|c|c|c|c|c|c}
\hline $\mathbf{p H}$ & $\begin{array}{c}\mathbf{E C} \\
\left(\mathbf{d S ~ m}^{-\mathbf{1}}\right)\end{array}$ & $\begin{array}{c}\mathbf{S O M} \\
(\boldsymbol{\%})\end{array}$ & $\begin{array}{c}\mathbf{C a C O}_{\mathbf{3}} \\
(\boldsymbol{\%})\end{array}$ & $\begin{array}{c}\text { Total N } \\
(\boldsymbol{\%})\end{array}$ & $\begin{array}{c}\mathbf{P}_{\mathbf{2}} \mathbf{O}_{\mathbf{5}} \\
(\mathbf{p p m})\end{array}$ & $\begin{array}{c}\text { Clay } \\
(\boldsymbol{\%})\end{array}$ & $\begin{array}{c}\text { Silt } \\
(\boldsymbol{\%})\end{array}$ & $\begin{array}{c}\text { Sand } \\
(\boldsymbol{\%})\end{array}$ & $\begin{array}{c}\text { Texture } \\
\text { class }\end{array}$ \\
\hline 7.09 & 3.97 & 2.49 & 7.15 & 0.15 & 179.3 & 47.6 & 13.8 & 38.6 & $\mathrm{C}$ \\
\hline
\end{tabular}

\section{Gyttja and gyttja compost}

The raw gyttja used in the experiment was obtained from the Kahramanmaras AfsinElbistan Lignite Operations Directorate. Before the experiment, some of the gyttja was composted with olive oil production waste called pirina $(\mathrm{pH}, 5.7 ; \mathrm{C} / \mathrm{N} \mathrm{50}$, organic carbon, $48.2 \%$ ) with microbial inoculation for eight months, according to the aerobic windrow method (Kavdir and Killi, 2008). Gyttja and pirina were mixed at a 1:1 ratio based on dry weight. In the experiment, both composted and uncomposted gyttja were used. Their properties are given in Table 2, which shows that composting gyttja improved its physical properties. Bulk density decreased from 0.65 to $0.59 \mathrm{Mg} \mathrm{m}^{-3}$, total porosity increased from 71 to $82 \%$, and water holding capacity increased from 206 to $270 \%$. In addition, the negative properties of gyttja such as high total $\mathrm{CaCO}_{3}$ content and improper particle size distribution were largely eliminated.

Table 2. Physical and chemical properties of composted and uncomposted gyttja

\begin{tabular}{|c|c|c|}
\hline \multirow[b]{2}{*}{ Properties } & \multicolumn{2}{|c|}{ Value } \\
\hline & $\begin{array}{c}\text { Uncomposted gyttja } \\
\text { (Yakupoglu et al., 2013) }\end{array}$ & Composted gyttja \\
\hline Ash (\%) & 61.79 & 66.2 \\
\hline Organic Carbon $(\%)$ & 22.16 & 19.6 \\
\hline $\mathrm{C} / \mathrm{N}$ & 12.6 & 17.07 \\
\hline $\mathrm{pH}$ & 7.01 & 6.42 \\
\hline $\mathrm{EC}_{25^{\circ} \mathrm{C}}\left(\mathrm{dS} \mathrm{m}{ }^{-1}\right)$ & 0.77 & 2.24 \\
\hline $\mathrm{CaCO}_{3}(\%)$ & 39.1 & 7.75 \\
\hline Bulk density $\left(\mathrm{Mg} \mathrm{m}^{-3}\right)$ & 0.65 & 0.59 \\
\hline Particle density $\left(\mathrm{Mg} \mathrm{m}^{-3}\right)$ & 2.25 & 2.21 \\
\hline Total porosity (\%) & 71 & 82 \\
\hline Water holding capacity $(\%)$ & 206 & 270 \\
\hline Total N (\%) & 1.76 & 1.15 \\
\hline Available $\mathrm{P}\left(\mu \mathrm{g} \mathrm{g}^{-1}\right)$ & 19.4 & 44.2 \\
\hline Total K $\left(\mu \mathrm{g} \mathrm{g}^{-1}\right)$ & 183 & 92 \\
\hline Total $\mathrm{Ca}\left(\mu \mathrm{g} \mathrm{g}^{-1}\right)$ & 122628 & 13892 \\
\hline Total $\mathrm{Mg}\left(\mu \mathrm{g} \mathrm{g}^{-1}\right)$ & 2348 & 3734 \\
\hline Total $\mathrm{Na}\left(\mu \mathrm{g} \mathrm{g}^{-1}\right)$ & 183.8 & 5.96 \\
\hline Total Fe $\left(\mu \mathrm{g} \mathrm{g}^{-1}\right)$ & 53.4 & 864 \\
\hline Total $\mathrm{Cu}\left(\mu \mathrm{g} \mathrm{g}^{-1}\right)$ & 6.62 & 145 \\
\hline Total Zn $\left(\mu \mathrm{g} \mathrm{g}^{-1}\right)$ & 5.86 & 307 \\
\hline Total Mn $\left(\mu \mathrm{g} \mathrm{g}^{-1}\right)$ & 28.7 & 0.54 \\
\hline
\end{tabular}




\section{Experimental design}

Incubation trials were carried out under controlled conditions $\left(22 \pm 0.5^{\circ} \mathrm{C}\right)$, in an air-conditioned unit with three repetitions. For this purpose, $1500 \mathrm{~g}$ of soil (dry weight) was sifted through a $<4 \mathrm{~mm}$ sieve, put into plastic pots, and homogenously mixed with $3 \%$ dry weight of composted or uncomposted gyttja. Five grass pea (Lathyrus sativus L.) seeds were planted in each pot, the soil was watered until moisture content reached field capacity and the pots were left to incubate. During incubation, moisture content was kept at field capacity with periodic watering. No fertilizers or pesticides were added. Pots without gyttja comprised the control group. Incubation lasted nine months and the trial consisted of a total of 54 pots. In the third, sixth and ninth months of the experiment, changes in physical and chemical properties of the soils were tested.

\section{Physical and chemical soil analyses}

We measured soil reaction $(\mathrm{pH})$ and electrical conductivity (EC) in a 1:2.5 soil-pure water suspension by Hanna pH-meter and EC-meter, respectively (Rowell, 1996), soil organic matter (SOM) by the modified Walkley-Black method (Nelson and Sommers, 1982), and total nitrogen (N) by the Kjeldahl method using Gerhardt automatic steam distillation system (Kacar, 1994). Available phosphorus (P) was determined spectrophotometrically (Rayleigh) from $\mathrm{NaHCO}_{3}$ extractions (Olsen et al., 1954) and the exchangeable cations $\left(\mathrm{Ca}, \mathrm{Mg}, \mathrm{K}\right.$ and $\mathrm{Na}$ ) were determined from $1 \mathrm{~N} \mathrm{NH} \mathrm{N}_{4} \mathrm{OAc}$ extractions (Thomas, 1982). Bulk density was determined using intact soil cores taken with Eijkelkamp 100- $\mathrm{cm}^{3}$ steel cylinders (Blake and Hartge, 1986). Aggregate stability (WAS) was determined by the wet sieving method (Kemper and Rosenau, 1986) and the mean weighted diameter (MWD) was determined by the dry sieving method (Demiralay, 1993) using Eijkelkamp equipment. All of the experimental procedures were repeated three times and results were averaged.

\section{Statistics}

The effects of the variables were tested with ANOVA and the Duncan test $(\alpha=0.05)$ was used to compare averages. Statistical evaluations were done in SPSS 22.0 (Efe et al., 2000).

\section{Results and discussion}

\section{Effects of composted and uncomposted gyttja applications on soil properties}

Physical and chemical analysis results performed at the end of the third, sixth, and ninth months of the incubation experiment are given in Table 3. This shows changes in soils with composted and uncomposted gyttja. For example, at the end of the third month, SOM was $3.08 \%$ for the control pot but $4.48 \%$ in pots with composted gyttja and $4.25 \%$ with uncomposted gyttja. Hence SOM was on average $5.11 \%$ higher in pots with composted gyttja and $5.33 \%$ higher in pots with uncomposted gyttja. At the end of the sixth and ninth months, SOM was also higher in pots with gyttja than in control pots, but after that SOM tended to decrease.

The average $\mathrm{N}$ in control pots with grass pea seeds decreased to $0.563 \%$ at the end of the ninth month, but the $\mathrm{N}$ content of pots with composted gyttja was maintained at 
$0.960 \%$. At the end of the ninth month, average changeable Ca concentrations were around $5700 \mathrm{ppm}$, but remained above $6000 \mathrm{ppm}$ at the end of the sixth and ninth months in pots with composted gyttja.

When Table 3 is examined in terms of $\mathrm{BD}$, which is one of the soil physical properties, it is understood that in all three sampling periods, decreases in BD values can be achieved by applying regulators in pots with and without plants. WAS, which is used as an evaluation index for the sensitivity of soils to water erosion, decreased from $55.3 \%$ at the end of the third and sixth months to $49.3 \%$ at the end of the ninth month.

Table 3. Mean values of measured dependent variables (C-gyttja: composted gyttja, UnCgyttja: uncomposted gyttja)

\begin{tabular}{|c|c|c|c|c|c|c|c|c|}
\hline Month & Plant & Treatment & $\begin{array}{c}\text { SOM } \\
(\%)\end{array}$ & pH & $\begin{array}{c}\mathrm{EC} \\
\left(\mathrm{dS}^{-1}\right)\end{array}$ & $\begin{array}{c}\mathbf{N} \\
(\%)\end{array}$ & $\begin{array}{c}\mathbf{P} \\
(\mathbf{p p m})\end{array}$ & $\begin{array}{c}\mathbf{C a} \\
(\mathbf{p p m})\end{array}$ \\
\hline \multirow{6}{*}{$3^{\text {rd }}$} & \multirow{3}{*}{ No plant } & Control & 3.08 & 7.95 & 0.653 & 0.583 & 7.41 & 5878 \\
\hline & & C-gyttja & 4.48 & 7.90 & 0.688 & 0.723 & 7.08 & 6062 \\
\hline & & UnC-gyttja & 4.25 & 7.87 & 0.671 & 0.830 & 8.38 & 5978 \\
\hline & \multirow{3}{*}{ Grass pea } & Control & 2.74 & 7.90 & 0.618 & 0.569 & 6.29 & 5843 \\
\hline & & C-gyttja & 5.11 & 7.92 & 0.663 & 0.960 & 7.22 & 6197 \\
\hline & & UnC-gyttja & 5.33 & 7.87 & 0.636 & 0.837 & 7.22 & 6065 \\
\hline \multirow{6}{*}{$6^{\text {th }}$} & \multirow{3}{*}{ No plant } & Control & 3.02 & 7.94 & 0.627 & 0.600 & 7.35 & 5825 \\
\hline & & C-gyttja & 4.21 & 7.90 & 0.660 & 0.730 & 7.38 & 6159 \\
\hline & & UnC-gyttja & 4.83 & 7.94 & 0.680 & 0.827 & 9.11 & 5944 \\
\hline & \multirow{3}{*}{ Grass pea } & Control & 2.90 & 7.94 & 0.576 & 0.580 & 6.85 & 5923 \\
\hline & & C-gyttja & 5.92 & 7.99 & 0.662 & 0.957 & 7.05 & 6184 \\
\hline & & UnC-gyttja & 4.88 & 7.90 & 0.692 & 0.730 & 7.80 & 6027 \\
\hline \multirow{6}{*}{$9^{\text {th }}$} & \multirow{3}{*}{ No plant } & Control & 3.01 & 7.89 & 0.699 & 0.583 & 7.03 & 5851 \\
\hline & & C-gyttja & 3.79 & 7.87 & 0.755 & 0.717 & 7.02 & 6022 \\
\hline & & UnC-gyttja & 3.82 & 7.84 & 0.811 & 0.823 & 8.87 & 5935 \\
\hline & \multirow{3}{*}{ Grass pea } & Control & 2.62 & 7.92 & 0.737 & 0.563 & 6.97 & 5792 \\
\hline & & C-gyttja & 4.23 & 7.94 & 0.739 & 0.960 & 7.09 & 6138 \\
\hline & & UnC-gyttja & 3.21 & 7.89 & 0.781 & 0.664 & 7.87 & 6037 \\
\hline Month & Plant & Treatment & $\begin{array}{c}\text { Mg } \\
(\mathbf{p p m})\end{array}$ & $\begin{array}{c}\mathbf{K} \\
(\mathbf{p p m})\end{array}$ & $\begin{array}{c}\mathbf{N a} \\
(\mathbf{p p m})\end{array}$ & $\begin{array}{c}\text { BD } \\
\left(\mathrm{Mg} \mathrm{m}^{-3}\right)\end{array}$ & $\begin{array}{c}\text { WAS } \\
(\%)\end{array}$ & $\begin{array}{r}\text { MWD } \\
(\mathbf{m m})\end{array}$ \\
\hline \multirow{6}{*}{$3^{\text {rd }}$} & \multirow{3}{*}{ No plant } & Control & 2017 & 375 & 41 & 1.04 & 55.3 & 1.514 \\
\hline & & C-gyttja & 1816 & 385 & 40 & 0.99 & 64.4 & 2.057 \\
\hline & & UnC-gyttja & 1933 & 492 & 44 & 0.98 & 65.7 & 2.497 \\
\hline & \multirow{3}{*}{ Grass pea } & Control & 1778 & 384 & 47 & 1.07 & 52.3 & 1.551 \\
\hline & & C-gyttja & 1811 & 396 & 44 & 1.00 & 64.9 & 2.220 \\
\hline & & UnC-gyttja & 1888 & 523 & 50 & 0.99 & 72.8 & 2.560 \\
\hline \multirow{6}{*}{$6^{\text {th }}$} & \multirow{3}{*}{ No plant } & Control & 2042 & 361 & 40 & 1.03 & 55.3 & 1.317 \\
\hline & & C-gyttja & 1876 & 371 & 39 & 0.99 & 72.0 & 1.789 \\
\hline & & UnC-gyttja & 1852 & 491 & 44 & 0.98 & 71.8 & 1.889 \\
\hline & \multirow{3}{*}{ Grass pea } & Control & 1734 & 381 & 46 & 1.05 & 55.2 & 0.997 \\
\hline & & C-gyttja & 1782 & 380 & 44 & 0.99 & 77.8 & 2.047 \\
\hline & & UnC-gyttja & 1862 & 518 & 50 & 1.00 & 62.5 & 2.119 \\
\hline \multirow{6}{*}{$9^{\text {th }}$} & \multirow{3}{*}{ No plant } & Control & 2046 & 354 & 40 & 1.06 & 49.3 & 1.502 \\
\hline & & C-gyttja & 1869 & 369 & 39 & 1.01 & 62.5 & 1.700 \\
\hline & & UnC-gyttja & 1837 & 477 & 44 & 1.02 & 67.9 & 1.893 \\
\hline & \multirow{3}{*}{ Grass pea } & Control & 1802 & 369 & 46 & 1.07 & 48.5 & 1.123 \\
\hline & & C-gyttja & 1776 & 366 & 44 & 1.01 & 70.0 & 2.133 \\
\hline & & UnC-gyttja & 1854 & 511 & 50 & 1.06 & 61.1 & 1.737 \\
\hline
\end{tabular}


WAS for pots without plants with composted gyttja were maintained around $70 \%$ at the end of both the sixth and ninth months.

Table 3 indicates changes in many properties of the test soils. ANOVA tests if sampling time, grass pea cultivation, or the fact that gyttja had been composted had an impact on these changes (Table 4). There were effects due to sampling time on $\mathrm{pH}, \mathrm{K}$ and BD ( $\mathrm{p}<0.05)$ and on SOM, EC, WAS, and MWD ( $\mathrm{p}<0.001)$. Time, as a source of variation, did not affect the remaining variables statistically. In other words, changes over time in $\mathrm{N}, \mathrm{P}, \mathrm{Ca}$, and $\mathrm{Na}$ concentrations were not statistically significant.

Table 4. Results of ANOVA showing the effect of variation sources on some soil properties

\begin{tabular}{c|c|c|c|c|c|c|c|c|c|c|c|c}
\hline \multirow{2}{*}{$\begin{array}{c}\text { Variation } \\
\text { Source }\end{array}$} & \multicolumn{10}{|c}{ Dependent variables } \\
\cline { 2 - 20 } & SOM & $\mathbf{p H}$ & $\mathbf{E C}$ & $\mathbf{N}$ & $\mathbf{P}$ & $\mathbf{C a}$ & $\mathbf{M g}$ & $\mathbf{K}$ & $\mathbf{N a}$ & $\mathbf{B D}$ & WAS & MWD \\
\hline Time & $* * *$ & $*$ & $* * *$ & $\mathrm{~ns}$ & $\mathrm{~ns}$ & $\mathrm{~ns}$ & $\mathrm{~ns}$ & $*$ & $\mathrm{~ns}$ & $*$ & $* * *$ & $* * *$ \\
Conditioner & $* * *$ & $*$ & $* * *$ & $* * *$ & $* * *$ & $* * *$ & $\mathrm{~ns}$ & $* * *$ & $* * *$ & $* * *$ & $* * *$ & $* * *$ \\
Plant & $*$ & $\mathrm{~ns}$ & $\mathrm{~ns}$ & $* * *$ & $* * *$ & $*$ & $* * *$ & $* * *$ & $* * *$ & $\mathrm{~ns}$ & $\mathrm{~ns}$ & $\mathrm{~ns}$ \\
\hline
\end{tabular}

$* \mathrm{P}<0.05 ; * * \mathrm{P}<0.01 ; * * * \mathrm{P}<0.001$

Table 5 shows the results of Duncan multiple-range tests of the variation sources for the measured averages. According to this table, there was no significant change in SOM at the end of the third (4.16a) and sixth (4.29a) months, but it did decrease by the end of the ninth month (3.44b); this difference was statistically significant. The $\mathrm{pH}$ of the soil was highest in the sixth month (7.93a) and there was no statistically significant difference between the third and ninth months. EC reached its peak at the end of the ninth month (0.753a), but was statistically identical after the third and sixth months.

Table 5. Comparison of dependent variable means with the Duncan test $(\alpha=0.05)(C$ gyttja: composted gyttja, UnC-gyttja: uncomposted gyttja)

\begin{tabular}{c|c|c|c|c|c|c}
\hline \multirow{2}{*}{$\begin{array}{c}\text { Dependent } \\
\text { variable }\end{array}$} & \multicolumn{5}{|c}{ Month } & \multicolumn{3}{c}{ Conditioner } \\
\cline { 2 - 7 } & 3rd & 6th & 9th & Control & C-gyttja & UnC-gyttja \\
\cline { 2 - 6 } SOM (\%) & $4.16 \mathrm{a}$ & $4.29 \mathrm{a}$ & $3.44 \mathrm{~b}$ & $2.89 \mathrm{~b}$ & $4.62 \mathrm{a}$ & $4.38 \mathrm{a}$ \\
$\mathrm{pH}$ & $7.90 \mathrm{~b}$ & $7.93 \mathrm{a}$ & $7.89 \mathrm{~b}$ & $7.92 \mathrm{a}$ & $7.91 \mathrm{a}$ & $7.88 \mathrm{~b}$ \\
$\mathrm{EC}(\mathrm{dS} \mathrm{m})^{-1)}$ & $0.654 \mathrm{~b}$ & $0.649 \mathrm{~b}$ & $0.753 \mathrm{a}$ & $0.651 \mathrm{~b}$ & $0.694 \mathrm{a}$ & $0.711 \mathrm{a}$ \\
$\mathrm{N}(\%)$ & $\mathrm{ns}$ & $\mathrm{ns}$ & $\mathrm{ns}$ & $0.579 \mathrm{c}$ & $0.841 \mathrm{a}$ & $0.785 \mathrm{~b}$ \\
$\mathrm{P}(\mathrm{ppm})$ & $\mathrm{ns}$ & $\mathrm{ns}$ & $\mathrm{ns}$ & $6.99 \mathrm{~b}$ & $7.15 \mathrm{~b}$ & $8.22 \mathrm{a}$ \\
$\mathrm{Ca}(\mathrm{ppm})$ & $\mathrm{ns}$ & $\mathrm{ns}$ & $\mathrm{Ns}$ & $5852 \mathrm{c}$ & $6127 \mathrm{a}$ & $5997 \mathrm{~b}$ \\
$\mathrm{Mg}(\mathrm{ppm})$ & $\mathrm{ns}$ & $\mathrm{ns}$ & $\mathrm{Ns}$ & $\mathrm{ns}$ & $\mathrm{ns}$ & $\mathrm{ns}$ \\
$\mathrm{K}(\mathrm{ppm})$ & $425 \mathrm{a}$ & $417 \mathrm{ab}$ & $407 \mathrm{~b}$ & $370 \mathrm{~b}$ & $377 \mathrm{~b}$ & $502 \mathrm{a}$ \\
$\mathrm{Na}(\mathrm{ppm})$ & $\mathrm{ns}$ & $\mathrm{ns}$ & $\mathrm{Ns}$ & $43 \mathrm{~b}$ & $42 \mathrm{~b}$ & $47 \mathrm{a}$ \\
$\mathrm{BD}\left(\mathrm{Mg} \mathrm{m}{ }^{-3}\right)$ & $1.01 \mathrm{~b}$ & $1.00 \mathrm{~b}$ & $1.04 \mathrm{a}$ & $1.05 \mathrm{a}$ & $0.99 \mathrm{~b}$ & $1.00 \mathrm{~b}$ \\
$\mathrm{WAS}(\%)$ & $62.5 \mathrm{~b}$ & $65.7 \mathrm{a}$ & $59.9 \mathrm{c}$ & $52.6 \mathrm{c}$ & $68.6 \mathrm{a}$ & $66.9 \mathrm{~b}$ \\
$\mathrm{MWD}(\mathrm{mm})$ & $2.066 \mathrm{a}$ & $1.692 \mathrm{~b}$ & $1.681 \mathrm{~b}$ & $1.333 \mathrm{~b}$ & $1.990 \mathrm{a}$ & $2.115 \mathrm{a}$ \\
\hline
\end{tabular}


Changeable $\mathrm{K}$ decreased over time and was statistically different in the third and ninth months. The lowest BD values were at the end of the third $\left(1.01 \mathrm{~b} \mathrm{Mg} \mathrm{m}^{-3}\right)$ and sixth (1.00 $\left.\mathrm{b} \mathrm{Mg} \mathrm{m}^{-3}\right)$ months, but higher $\left(1.04 \mathrm{a} \mathrm{Mg} \mathrm{m}^{-3}\right)$ at the end of the ninth month. The WAS average was highest at the end of the sixth month $(65.7 \mathrm{a} \%)$ and the lowest was at the end of the ninth month (59.9c\%). At the end of the sixth and ninth months, MWD was statistically the same; but at the end of the third month, it was higher; this difference was significant (2.066a $\mathrm{mm}$ ).

According to Table 5, SOM, EC, and MDW were not affected by composting. Both composted and uncomposted gyttja were statistically different from the control. The highest total $\mathrm{N}(0.841 \mathrm{a} \%)$, Ca $(6127 \mathrm{a} \mathrm{ppm})$, and WAS $(68.6 \mathrm{a} \%)$ were from pots with composted gyttja.

The results show that adding gyttja affected $\mathrm{Mg}$ and improved other soil properties. Although adding organic materials can significantly improve soils (Eigenberg et al., 2002; Ozdemir et al., 2009; Yakupoglu and Ozdemir, 2012; Gülser et al., 2015), they should not result in extreme values, especially in agricultural soils. Adding gyttja generally affected the measured variables positively, which leads us to a comparison of the effects of composted and uncomposted gyttja.

\section{Effects of composted and uncomposted gyttja applications on soil structural stability}

Since changes in structural stability are closely related to organic matter content (Barthes et al., 1999; Zhang et al., 2005; Tejada and Gonzalez, 2007; O'Brien and Jastrow, 2013; Cates et al., 2016), it is appropriate to evaluate the effects of organic regulators such as gyttja on structural strength and SOM. Adding gyttja improved levels of organic matter in the soil and as a result, there were other changes in WAS and MWD, which are indicators of structural resilience. The time-dependent changes in SOM, WAS, and MWD in pots with composted and uncomposted gyttja are shown in Figures 1-3. Figure 1 shows greater organic matter compared to control. The highest SOM values were reached at the end of the sixth month in pots with composted gyttja where grass pea was grown. Pots with uncomposted gyttja had higher SOM than control pots, but not as high as in pots with composted gyttja. In general, the decrease in SOM in the first six months in pots without plants was higher than in pots with plants. This can be attributed to the gradual decomposition of roots during the first six months, which contributed to the soil's SOM. At the end of the ninth month, SOM in pots with composted and uncomposted gyttja were similar, suggesting that plant roots were mineralized by then.

According to Figure 2, the highest WAS values were from samples taken in the sixth month from pots with plants and composted gyttja (77.8\%). At the end of the ninth month, the highest WAS values were in pots with composted gyttja, with or without plants. Uncomposted gyttja was also successful in increasing WAS compared to the control, but in these pots, WAS decreased dramatically after the sixth month. This tracks changes in SOM content.

According to Figure 3, the highest MWD in both pots with $(2560 \mathrm{~mm})$ and with plants $(2497 \mathrm{~mm})$ were at the end of the third month in soils with uncomposted gyttja. However, it should be noted that after adding uncomposted gyttja, there were dramatic decreases in MWD over time. Pots with composted gyttja were also been successful in increasing MWD compared to the control. MWD reductions were slower, especially in pots with plants. 


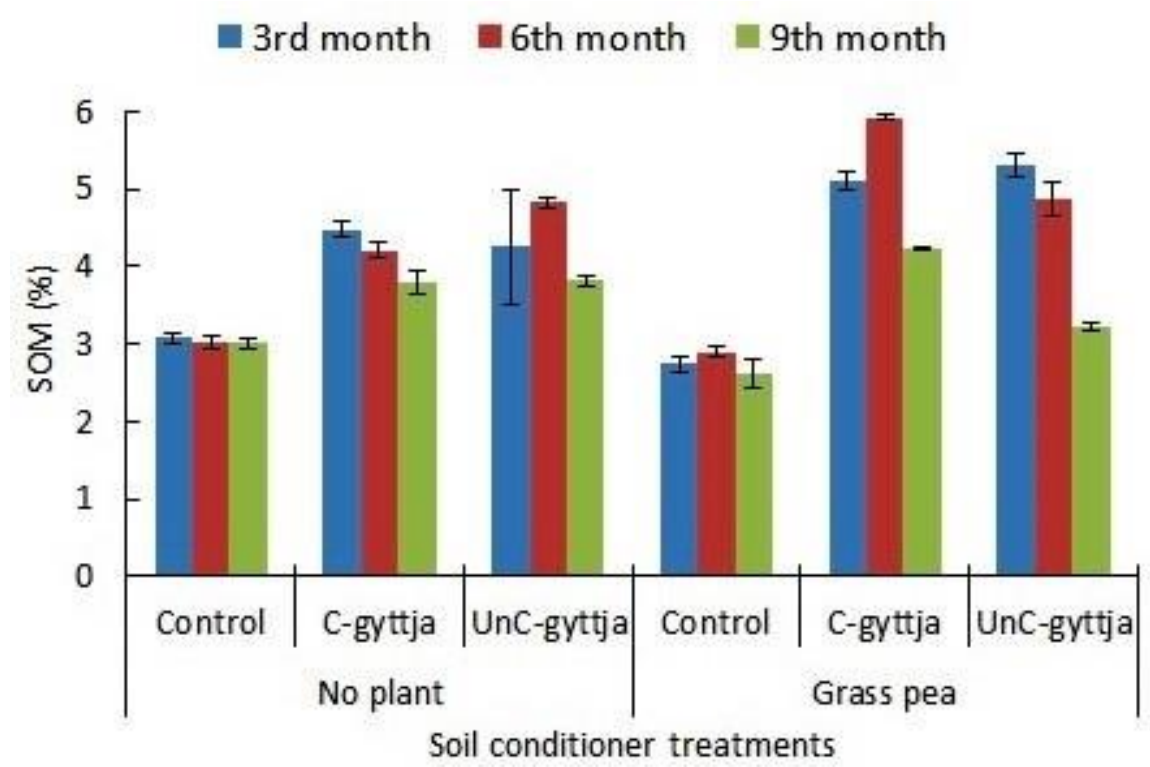

Figure 1. Changes in SOM of control, composted gyttja (C-gyttja) and uncomposted gyttja (UnCgyttja) treatments (Error bars represent the standard deviation of the replicates from the mean)

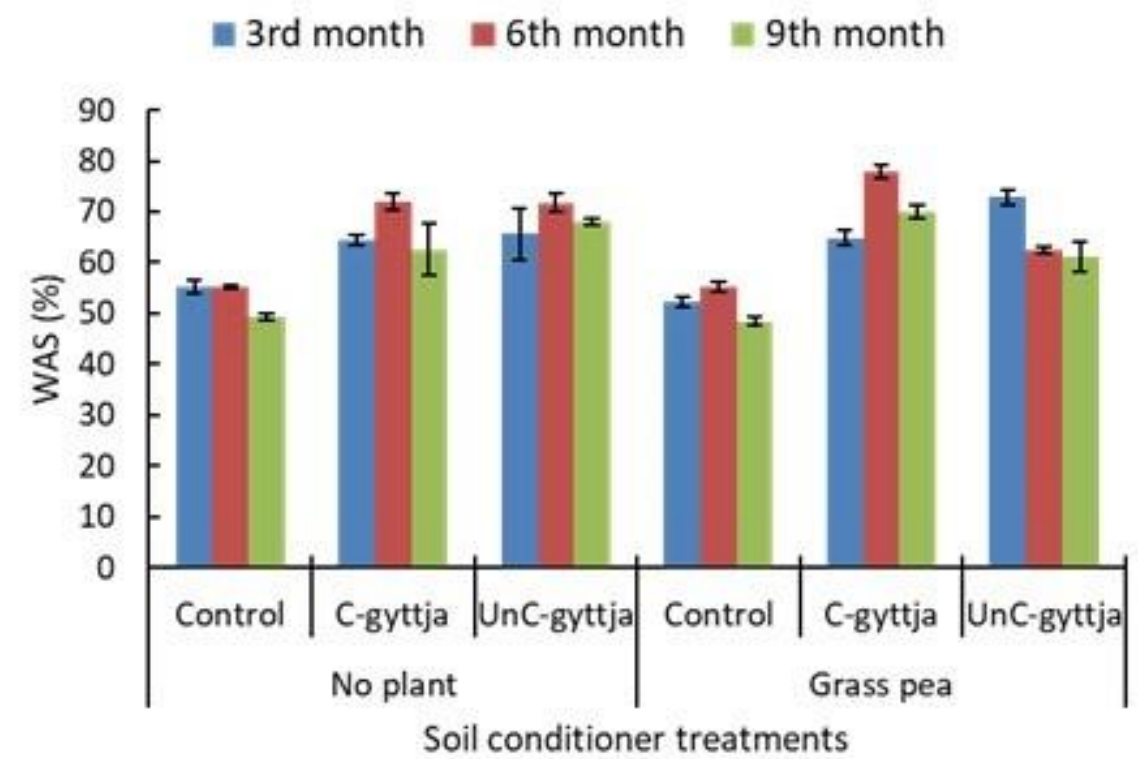

Figure 2. Changes in WAS of control, composted gyttja (C-gyttja) and uncomposted gyttja (UnCgyttja) treatments (Error bars represent the standard deviation of the replicates from the mean)

These results were achieved by adding organic material to the soil, which increased SOM, namely in pots with added gyttja and grass pea roots. The hydrophobic part of the organic substance, which does not have a uniform distribution, can slow water entry into the aggregate and increase resistance of certain parts of the aggregate against water dispersion, due to this water repellence feature (Varadachari et al., 1991; Miller et al., 2019). This would increase WAS. On the other hand, the degree of hydrophobicity of organo-mineral particles determines their ability to interact with water due to 
hydrophobic bonds. Due to the formation of hydrogen bonds, the formation of stable aggregates to water or the tendency to be subjected to peptization would emerge. Hydrophobic humus substances thus affect the stability of the aggregate with water as well as the formation of structural bonds (Piccolo and Mbagwu, 1999; Whalen et al., 2003; Milanovsky et al., 2013). This explains why the organo-mineral structures formed in soils with composted gyttja are stronger than those in soils with uncomposted gyttja. In turn, this explains why WAS was higher in soil with composted gyttja. In the first three months, uncomposted gyttja was more successful in increasing MWD, but thereafter, composted gyttja was more successful, especially in pots with plants. MWD is used as an index for soil sensitivity to wind erosion. Since uncomposted gyttja increases MDW in the short term, it would be better for semi-arid regions such as Topçu. For medium to long term processes, composted gyttja is better.

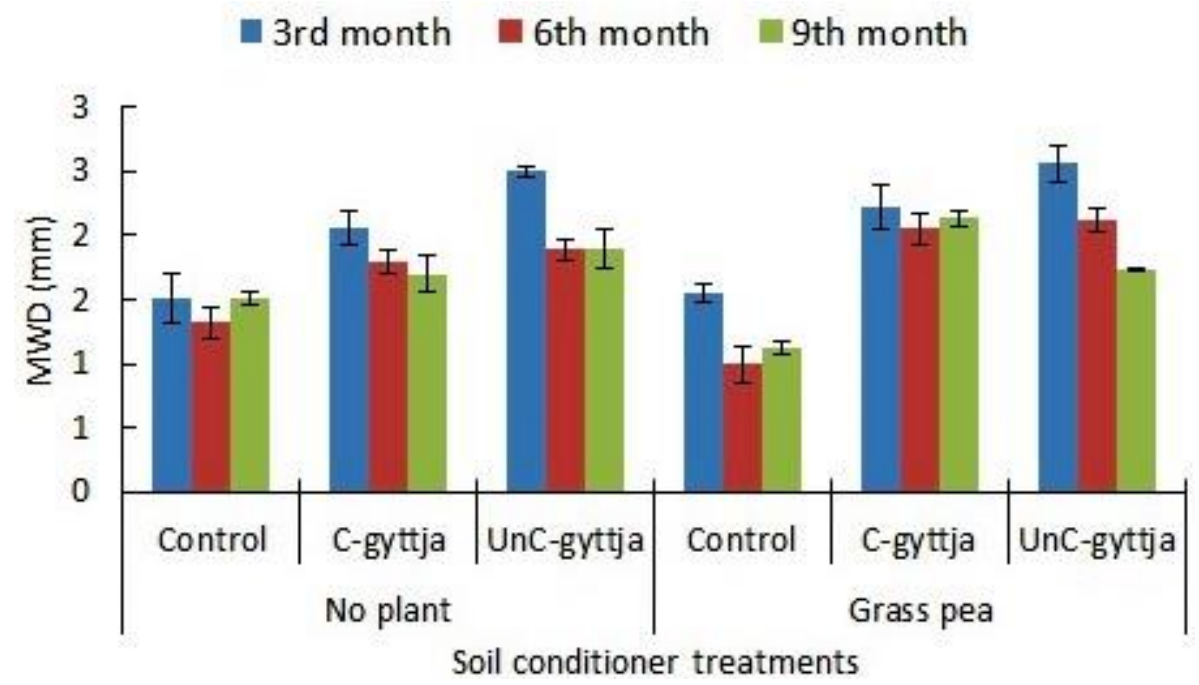

Figure 3. Changes in MWD of control, composted gyttja (C-gyttja) and uncomposted gyttja (UnCgyttja) treatments (Error bars represent the standard deviation of the replicates from the mean)

\section{Conclusions}

When composted gyttja is added to cultivated soil, it does not result in extreme soil values. It increases WAS more than uncomposted gyttja. If the goal is to combat shortterm wind erosion, uncomposted gyttja is more effective, but for long-term soil health, composted gyttja is better. Adding composted gyttja is more effective than uncomposted gyttja, since composting is an effective way to reduce its environmental damage as a waste product. Gyttja compost, which was prepared for this study, can be applied to plowed agricultural fields where forage crops are grown in semi-arid regions. Before adding composted gyttja to large areas, it is necessary to investigate the effects on different soils in each field. Only one-year forage crop (Lathyrus sativus L.) was cultivated in this study, and the changes caused by composted gyttja in the structural stability and some physico-chemical properties of the soil under grass pea were investigated. The effects of composted gyttja, especially reducing soil and water losses, should be investigated under different land and climate conditions. Changes in yield should be monitored and these studies should test different compost ratios doses and management techniques, which should be developed for each region. 
Acknowledgements. This work was supported by Yozgat Bozok University Project Coordination Application and Research Center [grant numbers 6602c/ZF/17-90]. The production of gyttja compost was carried out in the Composting Unit of Samsun Ondokuz Mayis University, Faculty of Agriculture. Incubation trials were carried out in an air-conditioned unit of Yozgat Bozok University, Faculty of Agriculture. We thank to mentioned institutions.

\section{REFERENCES}

[1] Avci, S. (2005): Thermal power plants in Turkey and their environmental effects. Istanbul University Geography Journal 13: 1-26.

[2] Aydin, G., Cullu, M. A., Ersahin, S., Akca, E., Erdogan, E., Atanir, L., Yorulmaz, A., Cilek, A., Ersoy, M., Miavaghi, S. R., Kapur, S., Lal, R. (2017): Mapping Soil Carbon: Stocks in Turkey. - In: Lal, R. (ed.) Encyclopedia of Soil Science. CRC Press, Boca Raton.

[3] Barthes, B., Albrecht, A., Asseline, J., De Noni, G., Roose, E. (1999): Relationships between soil erodibility and topsoil aggregate stability on carbon content in a cultivated Mediterranean highland (Aveyron, France). - Communications in Soil Science and Plant Analysis 30: 1929-1938.

[4] Becker, A., Bucher, F., Davenport, C. A., Flisch, A. (2004): Geotechnical characteristics of post-lacial organic sediments in Lake Bergsee, southern Black Forest, Germany. Engineering Geology 74: 91-102.

[5] Bischoff, N., Mikutta, R., Shibistova, O., Puzanov, A., Reichert, E., Silanteva, M., Grebennikova, A., Schaarschmidt, F., Heinicke, S., Guggenberger, G. (2016): Land-use change under different climatic conditions: consequences for organic matter and microbial communities in Siberian steppe soils. - Agriculture, Ecosystems and Environment 235: 253-264.

[6] Blake, G. R., Hartge, K. H. (1986): Bulk Density. - In: Klute, A. (ed.) Methods of Soil Analysis. ASA and SSSA, Madison, WI.

[7] Candemir, F., Gulser, C. (2011): Effects of different agricultural wastes on same soil quality indexes at clay and loamy sand fields. - Communication Soil Science Plant Analysis 42: 13-28.

[8] Cates, A. M., Ruark, M. D., Hedtcke, J. L., Posner, J. L. (2016): Long-term tillage, rotation and perennialization effects on particulate and aggregate soil organic matter. Soil and Tillage Research 155: 371-380.

[9] Del Buono, D., Said-Pullicino, D., Proietti, P., Nasini, L., Gigliotti, G. (2011): Utilization of olive husks as plant growing substrates: phytotoxicity and plant biochemical responses. - Compost Science \& Utilization 19: 52-60.

[10] Demir, O. F., Dikici, H., Yilmaz, K. (2017): Effect of gyttja and nitrogen applications on plant growth of red pepper (Capsicum annum L.) in the soils formed on the different parent materials. - Turkish Journal of Agriculture-Food Science and Technology 5: 807813.

[11] Demiralay, I. (1993): Soil Physical Analyses. - Ataturk University Faculty of Agriculture Publications, Erzurum, Turkey (in Turkish).

[12] Demirkiran, A. R., Cengiz, M. C. (2010): Effects of different organic materials and chemical fertilizers on nutrition of pistachio (Pistacia vera L.) inorganic arboriculture. African Journal of Biotechnology 9: 6320-6328.

[13] Edwards, L., Burney, J. R., Richter, G., MacRae, A. H. (2000): Evaluation of compost and straw on soil-loss characteristics in erosion plots of potatoes in Prince Edward Island, Canada. - Agriculture, Ecosystem \& Environment 81: 217-222.

[14] Efe, E., Bek, Y., Sahin, M. (2000): Statistical Methods with Solutions in SPSS II. - KSU Publications, Kahramanmaras, Turkey (in Turkish). 
[15] Eigenberg, R. A., Doran, J. W., Nienaber, J. A., Ferguson, R. B., Woodbury, B. L. (2002): Electrical conductivity monitoring of soil condition and available $\mathrm{N}$ with animal manure cover crop. - Agriculture, Ecosystem \& Environment 88: 183-193.

[16] Ersahin, S., Karahan, G. (2015): Soil Variability and Analysis. - In: Ersahin, S., Oztas, T., Namli, A., Karahan, G. (eds.) Soil Management. Gazi Publications, Ankara, (in Turkish).

[17] Gulser, C., Kizilkaya, R., Askin, T., Ekberli, I. (2015): Changes in soil quality by compost and hazelnut husk applications in a hazelnut orchard. - Compost Science \& Utilization 23: 135-141.

[18] Gunalay, M. E. (1971): Maras-Elbistan, Afşin Lignite Deposits Operation Project Final Report. - General Directorate of MTA Institute publications, Ankara, Turkey (in Turkish).

[19] Jarnuszewski, G., Meller, E. (2009): Total content of macroelements and trace elements in Holocene calcareous gyttja from the post-bog area of North-western Poland. - Soil and Water Research 14: 40-46.

[20] Kacar, B. (1994): Chemical Analysis of Plant and Soil III - Soil Analysis. - Ankara Univ. Agric. Fac. Education Research and Ext. Publication, Ankara (in Turkish).

[21] Karaca, A., Turgay, O. C., Tamer, N. (2006): Effects of a humic deposit (gyttja) on soil chemical and microbiological properties and heavy metal availability. - Biology and Fertility of Soils 42: 585-592.

[22] Kavdir, Y., Killi, D. (2008): Influence of olive oil solid waste applications on soil pH, electrical conductivity, soil nitrogen transformations, carbon content and aggregate stability. - Bioresource Technology 99: 2326-2332.

[23] Kemper, W. D., Rosenau, R. C. (1986): Aggregates Stability and Size Distribution. - In: Klute, S. (ed.) Methods of Soil Analysis. ASA and SSSA, Madison, WI.

[24] Larsson, R. (1990): Behaviour of Organic Clay and Gyttja. Report 38. - Geotechnical Institute Publications, Sweden (in Swedish).

[25] Mekki, A., Aloui, F., Sayadi, S. (2019): Influence of biowaste compost amendment on soil organic carbon storage under arid climate. - Journal of the Air \& Waste Management Association 69: 867-877.

[26] Milanovskiy, E., Rusanov, A. M., Shein, E. (2013): Dependence of aggregates water stability from the contents of hydrophilic and hydrophobic components in the organic matter of chernozems. - Eurasian Journal of Soil Science 2: 102-106.

[27] Miller, J. J., Owen, M. L., Ellert, B. H., Yang, X. M., Drury, C. F., Chanasyk, D. S. (2019): Influence of crop residues and nitrogen fertilizer on soil water repellency and soil hydrophobicity under long-term no-till. - Canadian Journal of Soil Science 99: 334-344.

[28] Miroslaw-Grabowska, J., Gasiorowski, M. (2010): Changes of water level in the Eemian palaeolake at Imbramowice (SW Poland) based on isotopic and cladoceran data. Quaternary Research 73: 143-150.

[29] Mpeketula, P. M. G., Snapp, S. S. (2018): Structural stability conditions soil carbon gains from compost management and rotational diversity. - Soil Science Society of American Journal 83: 203-211.

[30] Munsuz, N., Akyildiz, R. (1979): A Research on the Effects of Afşin-Elbistan Basin Lignite Coal Basin Gyttja on Physical Properties of the Regional Agricultural Soils. TUBITAK Project Final Report. No TOAG-301. TUBITAK Publications, Ankara (in Turkish).

[31] Namli, A., Akca, M. O., Akca, H. (2017): Determination of the usage areas of the organic materials which are found in the lignite pit of EUAS Afsin-Elbistan basin in agriculture.Soil Water Journal Special Issue: 46-54.

[32] Namli, A., Akca, M. O., Akca, H. (2019): Determination of the impacts of organic and organomineral fertilizers developed from the organic materials of Afşin-Elbistan basin lignite pit on the yield and yield components of wheat and on some soil characteristics. Soil Science and Plant Nutrition Journal 7: 10-20. 
[33] Nelson, D. W., Sommers, L. E. (1982): Total Carbon, Organic Carbon and Organic Matter. - In: Page, A. L. (ed.) Methods of Soil Analysis. ASA and SSSA, Madison, WI.

[34] O'Brien, S. L., Jastrow, J. D. (2013): Physical and chemical protection in hierarchical soil aggregates regulates soil carbon and nitrogen recovery in restored perennial grasslands. Soil Biology and Biochemistry 61: 1-13.

[35] Olsen, S. R., Cole, C. V., Watanabe, F. S., Dean, L. A. (1954): Estimation of Available Phosphorus in Soils by Extraction with $\mathrm{NaHCO}_{3}$. - USDA Cir. 939, Washington.

[36] Ozdemir, N., Yakupoglu, T., Dengiz, O. (2009): The effects of bio-solid and tea waste application into different levels of eroded soil on $\mathrm{N}, \mathrm{P}$ and $\mathrm{K}$ concentrations. Environmental Monitoring and Assessment 156: 109-118.

[37] Piccolo, A., Mbagwu, J. S. C. (1999): Role of hydrophobic components of soil organic matter in soil aggregate stability. - Soil Science Society of American Journal 63: 18011810.

[38] Robertson, G. P., Gross, K. L., Hamilton, S. K., Landis, D. A., Schmidt, T. M., Snapp, S. S., Swinton, S. M. (2014): Farming for ecosystem services: an ecological approach to production agriculture. - Bioscience 64: 404-415.

[39] Rowell, D. L. (1996): Soil Science Methods \& Applications. - Wesley Longman Limited, Harlow.

[40] Saltali, K., Yildirim, O. F. (2015): Effect of gyttja application on some plant and soil properties in confectionary sunflower (Helianthus annuus L.) cultivation at dry condition. - KSU Journal of Nature Science 19: 84-90.

[41] Stankevica, K., Burlakovs, J., Klavins, M. (2013): Organic rich freshwater sediments (sapropel) as potential soil amendment for recultivation of areas contaminated with heavy metals. - Proc. 13th SGEM GeoConference on Water Resources. Forest, Marine and Ocean Ecosystems, Albena, Bulgaria.

[42] Stankevica, K., Vincevica-Gaile, Z., Klavins, M. (2014): Influence of sapropel (gyttja) on trifolium pratense seeds germination in presence of copper. - Proc. 14th International Multidisciplinary Scientific GeoConference \& Expo, Albena, Bulgaria.

[43] Tamer, N., Karaca, A. (2006): Effects of gyttja and lignite on some enzyme activities of soil. - Selcuk Journal of Agriculture and Food Sciences 20: 14-22.

[44] Tejada, M., Gonzalez, J. L. (2007): Influence of organic amendments on soil structure and soil loss under simulated rain. - Soil \& Tillage Research 93: 197-205.

[45] Thomas, G. W. (1982): Exchangeable Cations. - In: Page, A. L. (ed.) Methods of Soil Analysis. ASA and SSSA, Madison, WI.

[46] Torun, B. (2009): The effect of gyttja application on cereal grain yield and soil physicalchemical properties in field conditions. - HRU Faculty of Agriculture Journal 13: 60-72.

[47] Torun, B., Yazici, A., Gultekin, I., Cakmak, I. (2003): Influence of gyttja on shoot growth and shoot concentrations of zinc and boron of wheat cultivars grown on zinc-deficient and boron-toxic soils. - Journal of Plant Nutrition 26: 869-881.

[48] Varadachari, C., Mondal, A. H., Gosh, K. (1991): Some aspects of clay-humus complexation: effect of exchangeable cations on lattice charge. - Soil Science 151: 220227.

[49] Whalen, J. J., Hu, Q., Liu, A. (2003): Compost application increase water-stable aggregates in conventional and no-tillage systems. - Soil Science Society of American Journal 67: 1842-1847.

[50] Yakupoglu, T. (2018): Some soil properties of agricultural land used for research purposes in Bozok region and various proposals for research to provide regional development. - Proc. 3rd International Bozok Symposium, Yozgat, Turkey.

[51] Yakupoglu, T., Ozdemir, N. (2012): Influence of some organic amendment on total porosity of an eroded soil. - Archives Agronomy and Soil Science 58: 195-200.

[52] Yakupoglu, T., Yilmaz, K., Demir, O. F. (2013): Some physico-chemical properties of gyttja as a soil conditioner; removed from Afsin-Elbistan coal power plant basin in Turkey. - Proc. ICOEST'2013 Conference, Nevsehir, Turkey. 
[53] Yuce, G., Yakupoglu, T. (2017): Effects of gyttja and polyacrylamide applications on some physical properties of soils with different texture. - Soil Water Journal Special Issue: 55-65.

[54] Zhang, B., Horn, R., Hallett, P. D. (2005): Mechanical resilience of degraded soil amended with organic matter. - Soil Science Society of American Journal 69: 864-871. 